Brit. F. vener Dis. (1974) 50, 151

\title{
Attempt to initiate community action programmes in venereal disease education in the United States of America
}

\author{
J. E. DE MUTH, J. R. ARNDT, AND M. H. WEINSWIG \\ Extension Services in Pharmacy and the School of Pharmacy, The University of Wisconsin, Madison, \\ Wisconsin, U.S.A.
}

There is little question that the control of the venereal diseases should be one of the major priorities of the various health professions in the United States of America. It is estimated that one American contracts a venereal disease every 15 seconds, and there are believed to be over half a million persons infected with syphilis in the United States and 2,000,000 new cases of gonorrhoea annually (Brown, 1971).

The steady increase in the number of cases has made it of paramount importance that efforts be directed toward their control. One of the essential elements of control is education. Venereal disease education does not necessarily change a person's sexual behaviour, but those with knowledge about the symptoms and effects of these infections will seek treatment sooner than those who are ignorant (Schwartz, 1971). Earlier diagnosis gives a greater likelihood of successful treatment, with fewer complications and better contact tracing.

The venereal diseases strike hardest among teenagers and young adults, so that venereal disease education must be given during adolescence. Children rarely receive any information about the venereal diseases from their parents and most of the facts they do acquire consist largely of misinformation from their friends (Benell; 1970). It would seem logical then to consider the schools as an acceptable avenue through which correct information could be disseminated to the young. Yet there are many schools which offer no venereal disease education and many others where teaching is sporadic (Brown, 1971).

One of the major deterrents to school instruction is the reluctance of teachers to discuss this type of subject. This attitude is due to their feelings of inadequacy (Benell, 1970). It is therefore necessary to instruct potential educators first, and to encourage their active involvement; such educators include not only school teachers, but also health professionals and concerned citizens who are willing to disseminate

Received for publication June 6, 1973 information to those in need of it. The purpose of this paper is to describe one such endeavour.

\section{'Venereal Disease and Society'}

In an attempt to fulfil the existing need for education about the venereal diseases, Extension Services in Pharmacy at the University of Wisconsin, Madison, Wisconsin (USA), developed and presented a course titled 'Venereal Disease and Society'. It was made available throughout the state utilizing the Wisconsin Educational Telephone Network (ETN) and consisted of five 2-hour sessions presented on Thursday evenings from October 14 to November 11, 1971. Each session included a 1-hour lecture followed by a question and answer period.

The course was designed with two major objectives. The first was to increase the participants' knowledge about the venereal diseases. Since it was impossible for this course to reach everyone in the State of Wisconsin, especially those who were more likely to contract one of these diseases, the second objective was to motivate the participants to educate others in their sphere of influence. It was hoped that these 'middlemen' would act as disseminators of information in their own communities, and educate those whom the course was unable to reach, particularly the younger people in the high risk groups.

Because it was felt that most people were not interested in discussing or learning about the venereal diseases, we used a method of communication, the Education Telephone Network, which could reach those few individuals throughout the state who were interested.

\section{The educational telephone network (ETN)}

The ETN is a private telephone network which links over 150 courthouses, hospitals, extension offices, and University of Wisconsin campuses 
throughout the state (Table I). Programmes originating on the Madison campus may be heard over a loudspeaker at any listening location on the network. If a student at any listening location desires to ask a question, he needs only pick up the telephone receiver and ask it. The question and the lecturer's response are heard at all the other locations on the network. This provides for two-way communication between the instructor and the learners.

TABLE I ETN listening locations in the State of Wisconsin

\begin{tabular}{lll}
\hline Institutions & $\begin{array}{l}\text { No. of locations } \\
\text { available }\end{array}$ & $\begin{array}{l}\text { No. of locations } \\
\text { used for the } \\
\text { 'Venereal Disease } \\
\text { and Society' course }\end{array}$ \\
\cline { 1 - 1 } $\begin{array}{l}\text { University of Wisconsin } \\
\text { centres and campuses }\end{array}$ & 14 & 9 \\
$\begin{array}{l}\text { Courthouses and agriculture } \\
\text { centres }\end{array}$ & 72 & 32 \\
$\begin{array}{l}\text { Hospitals and clinics } \\
\text { High schools }\end{array}$ & 65 & 1 \\
Libraries & 1 & 0 \\
Miscellaneous & 10 & 0 \\
\hline Total & 12 & 0 \\
\cline { 2 - 3 } & 174 & 42 \\
\hline
\end{tabular}

The ETN also provides a more economical method of disseminating information throughout the state than the traditional face-to-face technique of teaching, and has been shown to be just as effective (Blackwood and Trent, 1968). The Network thus provided Extension Services in Pharmacy with an effective and economical means of reaching those individuals throughout Wisconsin who were truly interested in the subject.

\section{Design of the course}

'Venereal Disease and Society' was geared for adult learners and designed to present the participants with factual information, no attempt being made to preach moral values or to employ scare tactics. The facts were presented on a level that laymen could understand, and technical matters were explained as simply as possible. To supplement the oral presentations, the participants were sent lecture guides for each session which included a brief outline of the lectures along with any graphs or other visual material discussed by the lecturer.

Additional material was also mailed to each learner; this included suggested outside reading, lists of available movies, and the physiology of the reproductive system. For those in the health professions information on drug therapy was also provided. All this printed matter was also designed to be used by those participants who were motivated to educate people outside the course. The lecture guides could serve as a reference source or as a format for preparing lectures by the participants themselves. The supplementary reading list could be used to obtain further information and also included booklets and pamphlets available for such things as school or pharmacy displays. The films were described so that they could be used in designing future presentations.

The first two lectures of the course dealt with syphilis and gonorrhoea. They were presented separately on two different evenings to prevent possible confusion on the part of the participants. Each lecture covered the historical background, present-day prevalence, means of infection, symptoms, results if left untreated, diagnostic methods, and effective treatments. The other venereal diseases were mentioned, but were not discussed in such great detail as syphilis and gonorrhoea.

After the participants had been provided with background information about syphilis and gonorrhoea, they were introduced to epidemiology and control procedures in the third lecture. Topics discussed included contact tracing, the importance of physicians reporting cases to state health departments, the confidential nature of these reports, and the use of diagnostic procedures in routine physical examinations.

The fourth lecture covered the social aspects of the spread of the venereal diseases, such as prostitution, homosexuality, wartime condition, and socio-economic considerations.

The fifth and most important lecture of the course focused on education and community involvement. It was intended to serve as a motivator to stimulate the participants to do something in their own communities with the knowledge acquired from the course. During the first four lectures the participants were presented with the facts; in the last lecture they were instructed how they could use them effectively. Emphasis was placed on the existing lack of education, the need for more education for the young, ways in which the learners could start community action in their own towns, and examples of how other communities had started programmes of instruction.

It should be noted at this point that 'Venereal Disease and Society' was concerned mainly with the importance of education and treatment in the control of venereal diseases. Discussion of prevention was minimal since, as already mentioned, it was not the intent of the course to preach moral values about sexual behaviour. Use of the condom was not discussed because existing law in the State of Wisconsin still classifies the condom as an 'indecent article'. There was some concern as to the extent to which it could have been discussed for prophylactic use. Without question, the use of the condom in 
preventing the spread of venereal disease should be included in educational programmes where outdated laws do not restrict the discussion of its use.

Two Wisconsin State laws were discussed at length during the fifth lecture and the students were encouraged to talk to their political representatives about them. As mentioned above, the first of these laws classifies condoms, as well as any device or method of birth control, as indecent articles. This means that they cannot be advertised or displayed, or their use advocated, and that published information about them cannot be circulated. The law also restricts their sale so that they can only be sold by registered pharmacists and, most important, it forbids their sale to unmarried individuals. Added to this barrier against venereal disease control is a second law which states that, if a minor is diagnosed as having a venereal disease, or for that matter any disease, he cannot be treated without his parent's permission. One wonders how many children in Wisconsin under 19 years of age have been diagnosed as having a venereal disease but have never returned for treatment because of embarrassment or fear of having their parents find out about their infection. At any rate, the students enrolled in 'Venereal Disease and Society' were encouraged to bring the facts to the attention of their political representatives in the hope of correcting the existing ignorance and lack of insight.

\section{Results of the course}

'Venereal Disease and Society' attracted 168 participants ranging in age from 14 to 67 years. These 65 men and 103 women represented a variety of occupations; there were 38 teachers, 40 social workers, 28 pharmacists, and 33 nurses, and the remainder were housewives, Parent-Teacher Association members, county extension agents, and college students. Of these participants, only 36.5 per cent. indicated that they had had any previous exposure to formal venereal disease education, and only 51 per cent. had ever attended an ETN type course (Table II).

The participants appeared to be highly interested in the course, and their rate of attendance, which was entirely voluntary, was gratifying (Table III). The lowest attandance, on November 4, was attributed to a statewide teachers' conference which was held during the same week.

All the participants were sent a pre-test before the first lecture and a post-test one week after the completion of the course. The data from this prepost-test design showed that the participants had increased their knowledge about the venereal
TABLE II Previous venereal disease education and ETN experience of the participants, by occupational status

\begin{tabular}{lll}
\hline Occupation & $\begin{array}{l}\text { Previous venereal } \\
\text { disease education } \\
\text { (per cent.) }\end{array}$ & $\begin{array}{l}\text { Previous ETN } \\
\text { experience } \\
\text { (per cent.) }\end{array}$ \\
\cline { 2 - 3 } & 27.8 & 66.7 \\
Pharmacists & 81.0 & 61.9 \\
Nurses & 30.4 & 21.7 \\
Teachers & 16.0 & 64.0 \\
Social workers & 29.4 & 41.2 \\
Miscellaneous & 36.5 & 51.0 \\
\hline Total participants & &
\end{tabular}

Based on 104 returned evaluation forms

TABLE III Attendance record of participants enrolled in 'Venereal Disease and Society', by lecture

\begin{tabular}{|c|c|c|c|c|}
\hline \multirow{2}{*}{ Date } & & \multirow{2}{*}{ Subject } & \multicolumn{2}{|c|}{ Attendance } \\
\hline & & & No. & Per cent. \\
\hline October & $\begin{array}{r}14 \\
21 \\
28 \\
4 \\
11\end{array}$ & $\begin{array}{l}\text { Syphilis } \\
\text { Gonorrhoea } \\
\text { Control procedures } \\
\text { Social factors } \\
\text { Education and } \\
\text { community action }\end{array}$ & $\begin{array}{l}163 \\
156 \\
156 \\
142 \\
\\
150\end{array}$ & $\begin{array}{l}97 \cdot 0 \\
92 \cdot 9 \\
92 \cdot 9 \\
84 \cdot 5 \\
\\
89 \cdot 3\end{array}$ \\
\hline \multicolumn{3}{|c|}{ Average total participation } & & $91 \cdot 3$ \\
\hline
\end{tabular}

diseases, but the most important aim of the course was their motivation to spread this information to others. To evaluate their involvement in venereal disease education a questionnaire was mailed to each registrant 6 months after the end of the course. It was found that before the course only 46 per cent. of the learners had tried to stimulate or participated in any form of venereal disease education, but in the 6 months after the course, 97 per cent. of them had stimulated or participated in at least one form of venereal disease education (Table IV).

TABLE IV Participants' involvement in venereal disease educaton before and after the course ${ }^{\star}$

\begin{tabular}{|c|c|c|}
\hline Type of involvement & $\begin{array}{l}\text { Before } \\
\text { the course } \\
\text { (per cent.) }\end{array}$ & $\begin{array}{l}\text { After } \\
\text { the course } \\
\text { (per cent.) }\end{array}$ \\
\hline $\begin{array}{l}\text { None } \\
\text { Informed family members } \\
\text { Informed people outside family } \\
\text { members } \\
\text { Designed or cooperated in the } \\
\text { designing of a venereal disease } \\
\text { education programme } \\
\text { Participated in presenting a } \\
\text { venereal disease education } \\
\text { programme } \\
\text { Talked to teachers or school board } \\
\text { members about existing venereal } \\
\text { disease education programmes in } \\
\text { local school system or starting new } \\
\text { programmes } \\
\text { Other activities }\end{array}$ & $\begin{array}{r}53 \cdot 7 \\
4 \cdot 6 \\
22 \cdot 2\end{array}$ & $\begin{array}{r}2 \cdot 8 \\
73 \cdot 2 \\
88.9\end{array}$ \\
\hline
\end{tabular}

*Based on 108 returned questionnaires 
Other activities reported included displays in schools and pharmacies, working in venereal disease clinics, helping local health departments in educational programmes, and attempts at modifying high school curricula to include more venereal disease education.

From an analysis of the test results and the questionnaires returned, it can be concluded that the course 'Venereal Disease and Society' fulfilled its objectives of increasing the participants' knowledge about the venereal diseases, and of motivating them to educate others in their sphere of influence about these infections.

\section{Conclusion}

The use of Wisconsin's Educational Telephone Network represents a new and effective approach to venereal disease education. The importance of the course 'Venereal Disease and Society' lies not only in the use of electronic communications, but in its attempt to motivate the students to initiate or advance venereal disease education in their own communities. Even though only 168 people participated in the formal presentation, it can be seen that many more received the information presented in the course. Any educational experience in the area of venereal diseases should devote some time to stressing the need to inform others and the importance of community action in controlling these infections.

\section{Summary}

'Venereal Disease and Society' was an educational course presented to 168 adults throughout the State of Wisconsin (USA) by means of a closed circuit telephone network. The course resulted in a significant increase in the participants' knowledge about the subject, and acted as a positive force to motivate the participants to educate others in their sphere of influence about these infections, especially the young people who are more likely to contract venereal disease.

\section{References}

BENELl, F. B. (1970) f. School Hlth, 40, 483

BlACKWOOD, H., and TRENT, C. (1968) 'A Comparison of the Effectiveness of Face-to-Face and Remote Teaching in Communicating Education Information to Adults'. Cooperative Extension Services, Kansas State University, Manhattan, Kansas

Brown, W. J. (1971) f. Amer. pharm. Ass., n.s. 11, 422

SchwarTZ, W. F. (1971) 'The VD Crisis'. Pfizer, New York

Une tentative pour instituer des programmes collectifs d'éducation antivénérienne aux Etats-Unis d'Amérique

\section{SOMMAIRE}

"Maladies Vénériennes et Société" fut le nom d'un cours éducatif dispensé à 168 adultes à travers l'Etat de Wisconsin (USA) au moyen d'un réseau téléphonique en circuit fermé. Le résultat du cours fut une augmentation significative des connaissances des participants sur la question, et il a agi comme une force positive pour conduire les participants à éduquer les autres sur ces sujets dans leurs sphères d'influence, spécialement les jeunes qui sont plus exposés aux maladies vénériennes. 